\title{
Lean Supply Chain Ecosystem for MSME a Framework for Phased Implementation
}

\author{
S. Dinakaran ${ }^{1}$, Dr. J. Clement Sudhahar ${ }^{2}$ \\ ${ }^{1} S$. Dinakaran, Research Scholar, Karunya University, Coimbatore, India \\ dinakaran1387@gmail.com \\ ${ }^{2}$ Dr.J. Clement Sudhahar, Professor, Karunya University, Coimbatore, India \\ clemns@gmail.com
}

\begin{abstract}
Supply Chain Management is the major operation tool for all the Industries. Micro, Small and Medium Industries are aware of the supply chain management but many of these companies have not yet followed this operation tool. In this scenario the Lean Supply Chain Management is also a part of the supply chain management, it means that how to minimize the supply chain cost and to use effectively without changing the time as well as reduce the time to deliver also. Based on the literature and Industry visit there are some gaps identified which affect the supply chain management and how it to be change into the Lean Supply Chain Management there are Communication, Information Sharing System, Cost control planning, Customer service, Industry trends, Customer linkages, Service philosophy, Seasonality Management Mindset, Lean Supply chain problem readiness, Supplier base, Data infrastructure Distribution center swaps and Lean Supply chain bottlenecks intervention. When the industry were fill this gaps the Supply Chain Management is to convert into the Lean supply Chain Management through this Micro, Small and Medium Industries can make their business well profitable and comfortable.
\end{abstract}

Indexing terms/Keywords:

Supply Chain Management, Lean Supply Chain Management, Micro, Small and Medium Industries.

\section{Council for Innovative Research}

Peer Review Research Publishing System

Journal: International Journal of Management \& Information Technology

Vol. 9, No. 1

editor@cirworld.com

www.cirworld.com, member.cirworld.com 


\section{INTRODUCTION}

In this article shows that the Micro, Small and medium scale Industries performance through the supply chain management. Many of this companies have the Supply Chain Management because of the fast processing but few of the companies were known about the Lean Supply chain management. This study based on the Coimbatore and Tirupur District Micro, Small and Medium Industries. Lean Supply Chain Management is essential for all the Industries because of Competition, Profit making, Demand, Price, Customer satisfaction, Productivity, Speed and Time management etc. The main objective of the Lean Supply Chain Management is to meet the predictable demand in the most efficient and with the cheapest way or without increasing the cost. Many of the large scale industries were following the Lean Management as well as Lean Supply Chain Management. This the Lean Management were identified only in the year of 1990's by Toyota hence the term Toyotism is also prevalent.

\section{Literature Review:}

\section{Lean Supply Chain Planning}

Micro, Small and Medium scale Enterprises work as suppliers with direct link with large-scale clients, face many challenges like relegated into lower levels of the Lean Supply chain. Very unlikely that small scale concerns will join with firms positioned at the intermediate level of the Lean Supply chain and address the problem being faced by them through resource planning. (Alberto De Toni etal., 1995). So this the article clearly states that there is a lack of Lean Supply chain planning in this MSME sector.

\section{Communication}

Sharon J. Williams (2006) concludes that Lean Supply-chain management is vital for the Micro, small and Medium Enterprises owing to the face that communication has been recognized among Enterprises and external bodies as a crucial link eliminating risk, delay and wastage of materials and manpower.

\section{Information Sharing System}

According to Mohd Nishat Faisal et al., (2006), information has emerged as the most important asset to create competitive advantage. Correct and timely information is more essential for all enterprises but this information sharing system is missing in micro, small and medium enterprises. The information risks are Information Security Risk, Information Distortion and Bullwhip Risk, Intellectual Property Rights Risk, Information System Breakdown Risk and Information Systems/Information Technology Outsourcing Risk. Information sharing system, if not tackled properly, can bring the whole Lean Supply chain to a halt.

\section{Cost control planning}

Ravulaparthy Ramarao (2012) argues that cost control is essential for the Micro, Small and Medium Enterprises. The cost control consist of operation and transaction cost reductions, optimizing transaction costs, cost-effectiveness and cost of services. In India rough estimates reveal the existence of about 133.68 lakh MSMEs (both registered and unregistered) in the country with more than 6,000 products and there units lose around $30 \%$ of their earning potential due to improper cost control planning. Therefore it is very imperative for MSME Sector to undertake this cost control planning very seriously as a part of Lean Supply chain management application.

\section{Customer service}

Customer services start from getting the order and end in delivering the goods and services. Customer services leading to Customer satisfaction play a major part of the Lean Supply chain management process improvements in the Micro, Small and Medium Enterprises. John C. Taylor et al., (2004) mentioned that customer services include attributes like in-stock customer service, Customer Loyalty, Customer retention, customer demand, preferences and customer purchasing habits. He also reiterated that the success in Micro Small and Medium Enterprises clearly required high levels of customer service as suggested.

\section{Identified Gaps: Industry trends}

Assessing the emerging trends and e application attributes, advantages and benefits that would vastly improve the scope of SCM application.

\section{Customer linkages}

Addressing the needs of who use the most profitable customers multiple channels (store, internet and catalog) to purchase products.

\section{Service philosophy}

Customer service philosophy requiring higher inventories than other retailers.

\section{Seasonality}

Smoothening large seasonal swings in business levels and product mix.

\section{Management Mindset}


Garnering the suspect of top management and in the bargain ensuring Top-Down approach.

\section{Lean Supply chain problem readiness}

Being aware of the impact of SCM impediments and creating a proactive environment rather than resorting to impact of their operating practices on the business a reactive fire-fighting environment.

\section{Supplier base}

Controlling the fragmented base suppliers who are involved in often multiple deliveries for one order, doubling or tripling the handling involved.

\section{Data infrastructure}

Back-end databases to interface between the companies. In order to gain an accurate end-to-end understanding of Lean Supply chain performance.

\section{Distribution center swaps}

Analyzing and zeroing in on the apt centers to minimize cost of inventories and transportation.

\section{Lean Supply chain bottlenecks intervention}

Distribution bottlenecks rise occurred as incoming and outgoing volumes overwhelmed employees.

\section{Conclusions:}

In the Micro, Small and Medium Industries there are only few of the companies known about the Supply Chain Management based on that can make it into Lean Supply Chain Management. For creating the Lean Supply Chain Management the Industries have to fill the gaps were identified so that Lean Supply Chain Management can develop for the Industries and then the Industries will run with well Profitable and Comfortable. This Lean Supply Chain Management is need for all the Industries because of cost efficiency, Competition, reduce waste, make the waste into profitable etc. So that the Lean Supply Chain Management is essential for all Micro, Small and Medium Industries.

\section{References:}

[1] De Toni, A., Nassimbeni, G., \& Tonchia, S. (1995). Small local firms inside the supply chain: challenges and perspectives. Small Business Economics, 7(3), 241-249.

[2] Williams, S. J. (2006). Managing and developing suppliers: can SCM be adopted by SMES?, International Journal of Production Research, 44(18-19), 3831-3846.

[3] Mohd Nishat Faisal, D.K. Banwet and Ravi Shankar (2006). "An Analysis Of The Dynamics Of Information Risk In Lean Supply Chains Of Select SME Clusters” The Journal of Business Perspective, 10 (4).

[4] Ravulaparthy Ramarao (2012). “Competitiveness of India's Micro, Small and Medium Enterprises through Functional Competencies: Role in Nation's Development" Vikalpa, 37(1).

[5] Taylor, J. C., Fawcett, S. E., \& Jackson, G. C. (2004). Catalog Retailer In-Stock Performance: An Assessment of Customer Service Levels. Journal of Business Logistics, 25(2), 119-137.

[6] Konecka, S. (2010). Lean and agile supply chain management concept in the aspect of risk management. Log Forum Selected full texts, 6 (3), 23-31.

[7] Faisal, M.N., Banwet D.K., Shankar, R. (2006). Mapping supply chains risk and customer sensitivity dimensions, Indusrial Management \& Data Systems, 106(6), 886.

[8] Fisher M. L., Jakiego łańcucha dostaw wymaga twój produkt?, Harvard Business Review Polska, luty 2005, 78.

[9] Schary, P. B., Skjott-Larsen, T. (2002). Zarządzanie globalnym łańcuchem podaży, Wydawnictwo Naukowe PWN, Warszawa, 127.

[10] Bhushan Sudhakar \& Clement Sudhahar, J. (2012), Logistics \& Supply Chain Management, (1st Edition) sun printer, p. 9.

\section{Authors Biography:}

S. Dinakaran doing Ph.D in Management discipline (Research Area - Supply Chain Management) at Karunya School of Business, Leadership and Management, Karunya University. Dinakaran1387@gmail.com

Dr. J. Clement Sudhahar is Professor of Marketing at Karunya School of Business, Leadership and Management, Karunya University, Coimbatore, India. (clemns@gmail.com) 